\title{
Okul Öncesi Dönemde Düşünme Becerilerinin Gelişmesinde Yaratıcı Bir Süreç Olarak Drama
}

\author{
Belma TUĞRUL* \\ Hacettepe Üniversitesi
}

\begin{abstract}
Özet
Okulöncesi dönem, ilkögretime başlamadan önceki yaşamın ilk altı yılını kapsar. Bu dönem fiziksel, sosyal, duygusal ve zihinsel gelişim dinamikleri açısından yaşamın en önemli yıllarıdır. Çocukların düşünme becerilerinin gelişimi dinamik bir süreçtir. Çocukların gelişsim sürecinde düşüncelerinin nasıl bir değişime uğradiğını bilmek onlarla ilgili doğru ve etkili öğrenme ortamlarının oluşturulması için gereklidir. Çocukların düşünceleri değerlidir çünkü kendi duygusal ve zihinsel süreçlerinin ürünüdür. Düşüncelerin somut ifadesi davranışlardır. Bu nedenle çocukların davranışlarının ardındaki düsünceyi bilmek davranışlar hakkında objektif yorum yapabilmek için gereklidir. Eğitimin amacı çocuklara bilgi, duygu ve düşünce aktarımı değil, bilgi, duygu ve düşünceleri oluşturma, kullanma ve öğrenmeye karşı güdülenmiş merak ve olumlu tutumlar geliştirmektir. Drama çocuklartn düşünsel yeteneklerinin gelişstirilmesinde çok önemli rol oynar.
\end{abstract}

Anahtar sözcükler: Okulöncesi, drama, düşünme, düşünce gelişimi, yaratıcllk

\begin{abstract}
Earlychildhood period includes the six years before the elementary school. This period can be called as crucial with respect to its physical, social, emotional, and cognitive dynamics. The development of thinking skills of children is a dynamic period. Knowing how do thoughts of children change is essential to make a proper and effective communication between children. The thoughts of children are valuable since they are the product of their emotional and cognitive periods. The behaviors are the concrete ways of thoughts. Because of this fact, it is necessary to know the thoughts of the children's behaviors to make an objective interpretation about their behaviors. The purpose of education is not to give knowledge, emotion and thought to the children, in contrast, it is aimed to develop creating positive attitudes, thoughts and emotions, arousing the curiosity in children. Drama plays a significant role in developing the thinking skills of children.
\end{abstract}

Keywords: Earlychildhood, drama, thinking, development of thinking, creativity

\footnotetext{
*Prof. Dr., Hacettepe Üniversitesi, İlköğretim Öğretmenliği Bölümü, Okul Öncesi Eğitimi Anabilim Dall, E-posta: btugrul@hacettepe.edu.tr
} 


\section{Giriş}

Okulöncesi dönem, ilköğretime başlamadan önceki yaşamın ilk altı yılını kapsar. Bu yaşamsal dönem fiziksel, sosyal, duygusal ve zihinsel gelişim dinamikleri açısından yaşamın en önemli yıllarıdır. İnsanı diğer canlılardan ayıran en önemli özellik onun düşünebilmesi, öğrenebilmesi ve hayal kurabilmesidir (Wood 1999). Düşünme becerisi, bilinen diğer canlılar içinde yoktur ya da çok ilkel seviyede bulunmaktadır. Düşünebilme becerisi nedeniyle insanoğlu, kendi hayatını kontrol edebilme kendi hayatına yön verebilme gücüne sahiptir. Bir başka deyişle düşünme gücü bireye geleceğini istediği gibi kurabilme sorumluluğunu yüklemektedir. $\mathrm{Bu}$ insanoğlunun doğuştan getirdiği doğal bir yetenektir. Yani birey, doğası itibariyle düşünme yeteneği ile donatılmış olarak dünyaya gelmektedir. İnsanoğlunu diğer canlı türlerinden üstün kılan düşünebilme yeteneğini onun yüksek yararı ve gelişmesinde firsat olarak kullanmak için en kritik dönem, okulöncesi yıllarıdır. Oktay (2000), okulöncesi dönemi yaşamın sihirli yılları olarak tanımlamaktadır. Erken çocukluk yılları olarak da tanımlanan okulöncesi dönem, çocukların büyüme, öğrenme, oyun oynama, güvende olma çağıdır. Milletler Cemiyetinin 1924'te Çocuk Hakları Cenevre Bildirgesi'ni benimsemesi ile çocukların yaşama, sağlık, eğitim, korunma ve katılma haklarının yaşama geçirilmesi taahhüt edilmektedir. 1989 yilında da BM Genel Kurulu tarafindan kabul edilen 192 ülkenin ve Türkiye'nin 1995 yılında dahil olduğu Çocuk Haklarına Dair Sözleşme ile çocukların yaşamaları, gelişmeleri ve korunmaları hayırseverlik işi değil, ahlaki ve hukuksal bir yükümlülük olarak kabul görmüştür (Unicef, 2006). Bütün bu bilgiler de desteklemektedir ki çocuklar güçlü toplumların güvencesi olarak özel ilgi ve desteğe layıktır. Çocuklar düşüncelerini ifade etme ve düşüncelerini geliştirme yönünde yetişkin dünyası tarafından çeşitli şekillerde engellenmektedir. Bazen koruyucu kollayıc1 ebeveyn olmak çocukların gelişmesi üzerinde tahminlerin üzerinde engelleyici olmaktadır (Baklaya \& Tuğrul, 1998). Çocukların düşüncelerine saygı duymak bir çocuk hakkıdır. $\mathrm{Bu}$ hakkın gereğini yapabilmek için çocukların nasıl düşündükleri hakkında bazı temel bilgileri hatırlatmak gerekmektedir.

Piaget (1971) küçük çocuğun öğrenme sürecini dünyaya uyum sağlaması olarak tanımlamaktadır. Çocuğun daha önce bildiklerinden oluşan zihinsel şemalarının yeni karşılaşılan durumlara uydurulması zihinsel bir eylemdir. Bu zihinsel eylem de doğrudan çocuğun düşünme özelliklerini yansitmaktadır. Piaget öğrenme sürecindeki zihinsel eylemlerin çocuğun düşünmesinin sonuçları olarak açıklamaktadır. Çocukların yetişkinler gibi düşünememesi gelişimsel olarak beklenen bir durumdur (Akt:Bjorklund, 1995).

Düşünme üzerinde düşünmek gerekir. Peki düşünme nedir? Düşünme, zihinsel bir işlevdir. Zihnin algılananları gözden geçirmesi ve tartışmasıdır. Aster (1945) düşünmeyi birleştirmek, parçalamak ve mukayese etmek olarak açıklamaktadır. Ancak, düşünme sadece zihinsel bir eylem değildir aynı zamanda sosyal bir üründür (Gökberk, 1994).

$\mathrm{Bu}$ nedenle çocukların düşünme becerilerinin geliştirilmesinin sosyal ve zihinsel yönden desteklenmesi gerekir.

Piaget'in zihinsel gelişim kuramında çocuğun düşünsel özellikleri gelişim dönemlerine göre farkl111k göstermektedir.

1- 0-2 yaş duyu-motor dönemde; model alma ve taklit etme kökenli davranışların ortaya çıkması, duyuların uyarılması ile algıya dayalı öğrenme.

2- 2-7 yaş arasındaki çocuklar işlem öncesi dönemde; $\mathrm{Bu}$ dönem düşünce becerileri açısından iki farklı döneme ayrılır: 
a. Sembolik İşlemler Dönemi 2-4 yaş: Sembolik düşünce gelişimi (nesne ya da hareketlerin bir başka şeyi temsil etmesi). Dilin ve dramatik oyunların kullanılmaya başlanması, kelime hazinesinde hızlı bir artış Ben-merkezci düşünce, animizm (canlı ve cansız nesneler arasında ayrım yapamama).

b-Sezgisel İşlemler Dönemi 4-7 yaş: Akıl yürütmelerin başlaması, nesneleri belirli bir özelliğe göre sinıflama ve sıralamada zorluk /güçlük yaşama, sayı korunumunu başaramama.

3- Somut İşlemler Dönemi/7-12 yaş Empati, mantıksal düşünme, olaylar arasında ilişki kurma, merkeziyetsizlik, karar verirken çok merkez/boyut/özellik kullanabilme. Korunum, dönüşebilirlik, çoklu sınıflama.

4-Soyut İşlemler Dönemi/12yaş ve üstü Analiz-sentez yapabilme, ergen egosantrizmi, aşırı idealizm, hayali seyirciler, soyut düşünebilme, soyut kavrama, hipotezler oluşturabilme ve aralarından seçim yapabilme (Bjorklund,1995; Tipton 2001).

Görüldüğü gibi çocukların düşünme becerilerinin gelişimi dinamik bir süreçtir ve basit ve somut düşünceden giderek daha üst düzeyde zihinsel işlemleri gerektiren soyut düşünmeye doğru gelişim gösterir. Çocukların gelişim sürecinde düşüncelerinin nasıl bir değişime uğradığını bilmek onlarla ilgili doğru ve etkili öğrenme ortamlarının oluşturulması için gereklidir.

Zekânın doğuştan belirlendiği ve değişmez olduğu düşüncesi, 21. yüzyılda terk edilmiştir.

Bugün bilinmektedir ki insanlar belli bir alanda genetik alt yapı ile dünyaya gelmiş olsalar da yüksek kalitedeki bir eğitim süreci zekâyı geliştirebilmektedir. Zekânın sözel ve matematiksel beceriler üzerine yoğunlaştı̆̆ 1 geleneksel zekâ testleri de Howard Gardner'in (1995) zekânın çok boyutluluğu fikrine yenik düşmüştür. $\mathrm{Bu}$ görüş bireyin farklı öğrenme gereksinimleri olduğuna dikkatleri çekmekle birlikte, çocukların her birinin farklı yollarla öğrendiği gerçeğini de göstermiştir. Zeka alanındaki bu değişme ve gelişmeler eğitimin öğrenme süreçleriyle ilgili olarak yeni uygulamalara temel oluşturmuştur. Böylece, bireylerin öğrenme gereksinimlerinin karşılanması için farklı olanaklar yaratmak, eğitim sisteminin temel sorularından biri olarak önem kazanmıştır (Dodge, Colker \& Heroman, 2002). Çocukların her biri farklı yolla öğrendiğine göre, öğrenme ortamının farklı öğrenme gereksinimleri ve öğrenme stilleri olan çocuklar için zenginleştirilmesi gerekmektedir. Öğrenmek için birçok kaynak vardır, bu kaynakları kendi yararına kullanma gücü, çocuğun kendisine aittir. Ancak öğretmenlerin çocukların öğrenme yollarını aydınlatıc1, rehber olması beklenmektedir. Ayrıca çocukların birbirlerine öğretme gücünden de yararlanmak gerekmektedir. Çocuklar birbirlerinin etkili öğretmenleridir. Çocukların her biri büyük düşünürlerdir. Çocuklara yardım etmek isteyen profesyoneller ve aileleri onları tanımak zorundadır. Çocuğu tanımak ise onların nasıl düşündüklerinin anlaşılmasını gerektirmektedir. Çocukların en çok yaptı̆̆ 1 şey düşünmektir. Bunun yanı sıra yetişkinlerin en az yaptığı şey de çocukların düşüncelerini anlamaya çalışmak ve onların düşünce gücünden yararlanmaktır. De Bono (1992) yetişkinlerin dünyaya çocukların gözünden bakarak düşüncelerindeki akıcılığı ve esnekliği beslemeleri gerektiğini vurgulamaktadır.

Çocuklar için düşünmek eğlenceli bir süreçtir; çünkü çocuklar düşünceleriyle oynarlar. Düşünmeyi zevkli kılan sadece bize tattırdığ 1 özgürlük duygusu değil, aynı zamanda bir şeyi yakalama, keşfetme heyecanıdır (Vosniadou, 2004; Wood 1999). Ancak geleneksel okulda çocuklar düşüncelerinden dolayı riske girerler çünkü ortak fikir üzerinde uzlaşma konusunda yüksek beklenti vardır. Çocukların otoriteyle bir başka deyişle öğretmenle ve diğer arkadaşlarıyla 
aynı fikirde olmas1, olas1 beklentilerle sinırlı düşünceler dışındaki farklı cevaplara tahammülsüzlük çocukların düşünme gücünü geliştirmelerini riske sokar.

Rousseau "çocukluğun kendine has görme, düşünme ve hissetme tarzı vardır; hiçbir şey kendi tarzımızı onlarınkinin yerine koymak ve onlara kabul ettirmeye çalışmak kadar yanlış olamaz" demektedir (Akt:Alexander,1995). Weikart ve Hohmann (2000) ise, çocukların çevrelerindeki dünyayı anlamak için çevreleriyle düşünerek etkileşime girdiklerini belirtmektedirler. Çocukların dünyayı anlamasının hareket etme ve sorular sorma yoluyla gerçekleşebileceğine dikkati çekmektedirler. Ancak bu arada çocukların yetişkinlerden ve birbirlerinden de farkl düşündükleri üzerinde durmaktadırlar. Çocukların düşüncelerindeki bu farklılığın özgün sonuçlar nedeni olarak açıklamaktadırlar.

Çocuklarımızın farklılıkları fark etmesini sağlamak önemlidir ancak asıl olan çocukların farklı olma cesareti göstermelerini sağlamaktır. Farklılıkları fark etmek farkl11ıkları kabul edebilmek için ilk adımdır. İnsanların temel gereksinimleri içinde başkaları tarafından kabul ve onay görme gereksinimi bulunmaktadır (Isenberg ve Jalongo, 2001). Başkalarının görüş açısı içinde olmak genel olarak onaylanan toplumsal bir değerdir. Geleneksel okul, öğrencilerinin kendilerini öğretmenlerine, anne ve babalarına beğendirmelerini desteklemektedir. Bu da bireyin kendi ile ilgili olarak başkalarının karar ve sorumluluklarına bağımlı olduğu "dıştan denetim odağı" gelişmiş bireylerin yetişmesine neden olabilmektedir. Kendi duygu, düşünce ve davranışlarının kontrolünü elinde bulundurabilen bir başka deyişle içten denetim odağı gelişmiş olanlar yaşam kalitesi yüksek bireyler topluma faydalı olabilmektedirler. "Farklı olmak" kavramının zihinlerde ilk çağrıştırdığı anlam; kural dışı olmak, uyumsuzluk, çatışma vb. gibi negatif duygu ve düşünceler olsa da "farklı olmak" aslında bu negatif algılarla baş edebilecek kadar yüksek öz güven ve kararlılık ifadesini içermektedir.

Çocukların düşünceleri değerlidir çünkü kendi duygusal ve zihinsel süreçlerinin ürünüdür. Düşüncelerin somut ifadesi davranışlardır. $\mathrm{Bu}$ nedenle çocukların davranışlarının ardındaki düşünceyi bilmek davranışlar hakkında objektif yorum yapabilmek için gereklidir. Birçok öğretmen, çocukların sıradışı, alışılmamış düşüncelerinden korkar çünkü alışılmışın dışındaki düşüncelerle başa çıkmak, bunu gelişim yönünde bir firsat olarak kullanmak üst düzeyde öğretmen yeterliliğidir. En önemlisi farklılıkları kabul edebilmek için yaratıcı düşünmenin gücüne inanmak ve kendi düşünme biçimini de bu boyutta geliştirmeye açık tutmak gerekir. Yaratıcı düşünce yaratıcı öğretmen ve anne babaların sağlayacağ 1 olanaklarla geliştirilebilmektedir (Isenberg \& Jalongo, 2001). Çocuklar yaratıcı güçlerini fark etmek ve kullanmak için yaratıcı modellere gereksinim duymaktadirlar. $\mathrm{Bu}$ nedenle model yaratıcıllğ gerekir. Yaratıcılığın engeli model değil, modele bağımlılık yaratan yetişkin davranış ve tutumlarıdır.

Anaokullarında çocukların farklı düşünme yollarının desteklendiği çok sayıda firsat sunmak mümkündür. Böylelikle çocuklar kendi düşünme süreçleri ve ürünleri dışındaki örnekleri de görme şansı bularak kendilerini geliştirebilmektedirler. Örneğin Hacettepe Üniversitesi Beytepe Anaokulunda "Matematik Kutusu" olarak tanımlanan bir çalışma kapsamında çocukların boynuna bir rakam kolyesi takılmakta ve çocuklar ertesi gün anaokuluna gelirken rakam kolyelerindeki rakamı temsil eden sayıdaki nesneleri matematik kutularına koyup gelmektedirler. Örneğin 3 rakamı ile ilgili olan çocuklar, kutularına koydukları şeylerden üçer tane koymak durumundadırlar. 3 rakamıyla çalışan bir çocuk kutusuna üç mandal, üç ataç, üç 
araba, üç peçete vb koymuşken, 3 rakamıyla çalışan başka bir çocuk kutusuna üç pipet, üç anahtarlık, üç havlu, üç bayrak vb koymuş olabilmektedir. Böylece çocuklar aynı rakamla çalışalar bile farklı şekilde düşünüp farklı ürünler üzerine odaklandıklarını fark edebilmektedirler. Çözülmesi gereken problem aynı olsa bile çözümler çok sayıda ve birbirinden faklı olabilmektedir. Çocukların aynı konuda farklı düşünme olasılıklarını geliştirmeye yönelik bir başka çalışma da çocukların sadece ipleri ve beyaz kağıdı kullanarak ürünler oluşturmasına yöneliktir. $\mathrm{Bu}$ aynı zamanda, çocukların aile katılım programı kapsamında planlanan bir çalışmadır. Özellikle küçük çocukların ailelerinin sürece dahil olması ve çocuklarının düşünme biçimlerini anlayabilmeleri açısından önemlidir. “İpler ve Beyaz Kağıt" projesi anne ve babaların çocuklarıla nitelikli zaman geçirmesini de hedeflemektedir. Evde yapılan çalışmalar okulda sergilenerek çocukların kendi dışındaki farklı ve özgün örnekleri görmesi sağlanmıştır (Tuğrul, 2007). Çok sayıdaki ürün çok sayıdaki farklı düşüncenin sonucudur. Ancak birçok okulda çocukların birbirinin aynısı olan ürünleri yapma konusunda yönlendirildiği görülmektedir. Çocukların kendi düşünme sürecinin ürünleri dışında "başka ve farklı" ürünleri görmesi için yaratıcı öğretmenlere ve yaratıcı yöntemlere gereksinim vardır. Anaokulunda uygulanan bir başka örnek de çocukların problem çözme sürecine yönelik olarak yapılan "Sen Olsan $\mathrm{Ne}$ Yaparsın" çalışmasıdır (Tuğrul, 2007). Bu çalışma kapsamında öğretmen çocuklara çeşitli problem durumları vermekte ve çocuğun bu problem için önerilerini sormaktadır. Örneğin "Arkadaşın da sen de aynı oyuncakla oynamak istediniz ama ondan sadece bir tane var ve arkadaşın senden önce oyuncağı almış. Bu durumda ne yapmayı düşünürsün?”, ya da “Arkadaşlarına sürpriz yapmak istedin ve onlara birer şeker armağan etmeyi düşündün fakat okula geldiğinde birkaç şekerin eksik olduğunu fark ettin. Bu durumda ne yapmayı doğru bulursun?" gibi çeşitli sosyal problemlere çözümler üreten çocuklar, düşünme becerilerini geliştirerek sosyal iletişim becerilerini de güçlendirme firsatı bulabilmektedirler, ayrıca bu tip çalışmalar çocukların dil becerilerini ve olasıllkları düșünme becerisini de geliștirerek günlük problemlerle baş etme gücü ve güveni de sağlayabilmektedir.

Çocukların düşüncelerini deneyimleri besler, buna gelişimsel süreç de eşlik eder. Bu nedenle çocukların düşünme becerilerinin geliştirilmesinde çevre tarafından sunulan olanakların bilinçli olarak güçlendirilmesi gerekmektedir. Çocukların düşünmesini tetikleyen en güçlü en doğal, en pratik ve ekonomik yol, soru sormaktır. Sungur (1997) yaratıcı bireylerin yaşama yönelttikleri çetin sorularla etkinliklerini başlattıklarını vurgulamıştır. Frank Kindom ise soru sormay zekanın yaratıcı eylemi olarak tanımlamaktadır (Akt:Sungur 1997, s.138). Düşüncenin yönlendirile bilmesi ve geliştirilmesi soru sormakla mümkündür. Doğru yanıtlar ancak doğru sorularla elde edilebilir. Soru sorma, aslında bir gereksinimin ifadesidir. Onun da arkasinda merak güdüsü vardır. Tarih boyunca yaşamış olan bütün ünlü bilim adamlarının ortak yönü yaşadıkları dünyayı merak etmiş olmalarıdır. Bilimin ve buluşun keşif kaynağ (Gelb, 2004). Bunun en iyi örneği fizik alanında 1934 y1lında Nobel ödülünü alan İtalyan fizikçi Carlo Rubbia'nın kendisiyle röportaj yapan gazetecilere verdiği yanıtta açıkça vurgulanmıştır. Rubbia, kendisine nasıl başardınız sorusunu soran gazetecilere "Annem her gün bana bugün okulda aferin aldın $\mathrm{m} ı$ diye sormak yerine bugün öğretmenine hiç soru sordun mu diye sorardı." yanıtını vermiștir. $\mathrm{Bu}$ nedenle doğru soruyu sormak öğrenmenin dolayısıyla düşünmenin ilk aşamasıdır. Sorular yeni düşünceler oluşturur ve mevcut düşüncelerin kullanılabilirliğini sağlar. Sorular düşünmenin sonucudur. Eğitimin amac1 
çocuklara bilgi, duygu ve düşünce aktarımı değil, bilgi, duygu ve düşünceleri oluşturma, kullanma ve öğrenmeye karşı güdülenmiş merak ve olumlu tutumlar geliştirmektir. Geleneksel okul sorulara değil doğru ve tek yanıtın bulunmasına yönelmektedir. $\mathrm{Bu}$ okullarda ödüllendirilen düşünce biçimi doğru yanıtı bulmaktır. Oysaki çocukların doğal merakı tümüyle sorulara odaklanmıştır. Çocukların ilgisini çekmek, merak uyandırmak ve bunu düşünmeye yöneltici sorularla geliştirmek gerekir. Burada önerilen, doğru yanıttan çok "doğru soruyu" bulmaktır. Daha önce sorulmuş yanıtları bilinen sorular yerine daha önce hiç sorulmamış olan soruları sormaya cesaretlendirilmek önemlidir (Prashing, 1996). Daha önce sorulmuş ve benzer yanıtlar alınmış soruların olası başka yanıtlarının olabileceğine dikkati çekmek ve "başka" sorusuyla sorgulama ve yeniden gözden geçirme sürecinin geçirilmesi de önemlidir. Çocukların düşünmek için zamana gereksinimi vardır. Çocuklar kendilerine hazır olarak sunulan bilgileri ezberlemek durumunda kaldıklarında ve bu bilgiler de çok fazla olduğunda düşünmek için zaman bulmak imkânsızlaşmaktadır. Yanıtını içinde barındıran sorular da çocuk için zaman kaybıdır. $\mathrm{Bu}$ tip sorular düşünmeyi tetikleyici değil düşünmeyi engelleyici ve bağımlılık geliştiricidir. Oysaki çocuğun düşünce üretebilmesi için kendi kendine kalmaya gereksinimi vardır. Düşünme öğrenilebilir ve geliştirilebilir bir beceridir.

Düşünmenin karar verme, planlama, yenilikler ve sorun çözme boyutları ile mantıksal düşünmeden yaratıcı, yanal (Lateral) düşünmeye doğru gelişim göstermesi desteklenmelidir (Isenberg \& Jalongo, 2001). Birçok yetişkin, düşünmenin kendiliğinden gelişen bir beceri olduğunu düşündüğü için, özel olarak düşünme becerilerinin öğretilmesiyle ilgilenmemektedir. Tabi ki düşünce gelişimsel bir süreç izler ancak bu sürecin etkili öğretim yöntemleriyle desteklenerek güçlendirilmesi de mümkündür.

Drama çocukların düşünme becerilerinin gelişmesinde etkili yöntemlerden biridir. Özellikle küçük yaşlardaki çocuklarla yapılan drama çalışmaları yaşantılara dayalı deneyimleri harekete geçirmeyi hedeflemektedir. Çünkü bu deneyimler çocuklar için gerçek, somut ve kişiye özeldir (Tuğrul, 2005).

Çocuklar yetişkinlerin küçük kopyaları değildir. Kendilerine özgü gereksinimleri, ilgileri ve düşünce yapılarıyla tamamen kendilerine özgün varlıklardır. Tıpkı kar taneleri gibi. Kar tanelerinin hiçbiri birbirinin aynısı değildir. Çocuklar birbirleriyle ortak özellikler gösterseler de özgünlüklerini koruma yolunda doğal dirençler gösterirler. Yetişkinlerin çocukların kendi varoluşlarını kanıtlamanın ispatı olan bu direnişleri gelişme yönünde firsat olarak değerlendirmesi beklenir. Örneğin tanışma ile başlayan bir drama sürecinde çocukların kendileri hakkında düşünmelerini sağlayacak sorular sorulabilir. Çocuklar oturuyorlar ise ayağa kaldırılır. Ayakta duran çocuk grubuna "ben size ne söylersem oturursunuz? ya da oturmanız için size ne söylemem gerekir? ya da oturmanızı sağlamam için bir şey söylemek dişında ne yapabilirim?" vb. gibi çeşitli sorular sorulabilir. Burada önemli olan çocukların oturmasını sağlamak değil her gün onlarca kez yapılan bir rutin davranış hakkında düşünmelerini sağlamaktır. Çocuklardan alınan birçok yanıt olacaktır. Eğitimci her bir yanıtın iyi fikir olduğunu söyleyerek yüceltme yapar ve ardından "başka, başka, başka" sorularıyla çocukları farklı fikirler üretmesi için cesaretlendirir. "Başka" sihirli bir sözcüktür. Çünkü düşünme gücümüzü kullanma konusunda seçeneklerin varlığına dikkat çeker. $\mathrm{Bu}$ da çocukta seçenekli (olasılıklı) düşünme, yaratıcı düşünme, ışınsal düşünme, rraksak düşünme, eleştirel düşünme, yanal düşünme vb. gibi aslında süreç ve işlem olarak 
farklı, fakat düşünmedeki akıcıllı̆ı, esnekliği ve orijinalliği ifade etme açısından benzerlik taşıyan düşünme becerilerinin gelişmesini sağlar

Oyunumuza geri dönecek olursak; eğitimci, çocuklardan aldığı yanıtlardan sonra süreci kendi planladığı şekilde sürdürür. Bazı olası durumlar söyler ve bu özellikleri taşıyanların oturabileceğini duyurur. Örneğin, "Sabah kahvaltısında ballı süt içenler otursun, okula gelirken iç çamaşırını değiştirenler otursun, evden çıkarken iki komşusuyla karşılaşanlar otursun, yolda gelirken herhangi bir hayvan görenler otursun" vb. gibi yakın geçmişle ilgili sorular sorulabileceği gibi daha uzak geçmişle uzun süreli belleklerini kullanabilecekleri sorular da sorulabilir. Örneğin, bayram tatilinde başka bir şehre tatile gidenler, ailesinde ya da komşuları arasında yeni bir bebeğin doğduğunu bilenler, yatmadan kitap okuyan anne ve babası olanlar vb. Aslında bu soruların her biri çocukların kendi yakın ve uzak çevrelerini, yaşamlarını gözden geçirmeleri için düşünsel bir eylem planıdır. $\mathrm{Bu}$ çalışmada sorulan sorular düşünmeye yöneltici sorulardır. Yanıtlardan çok sorular önemlidir. Drama bireyin kendi ile yüzleşme sürecidir. Dramanın doğasında etkileşim vardır (Tuğrul, 2005). Bu çalışmada da çocuğun grup içinde bireysel gereksinimleri karşılanmış olmakta ve birbirlerinin hayatına ilgi duyarak etkileşim ortamı yaratılmaktadır. Üstelik dramanın çok temel kazanımlarından biri olan çevre hakkında duyarlılık geliştirme de bu süreçte desteklenmektedir. Drama yaşamın kendisini yansıttığı için çocuklar için öğrenme anlaşılabilir, basit fakat ilginç olarak gerçekleşmektedir. Burada sunulan çalışmanın drama sürecinin tanışma, ısınma aşamasıyla ilgili bir örnek olduğu ve sürecin devam edeceği düşünülmelidir.

$\mathrm{Bu}$ çalışma ortak özellikler taşıyan çocukların bir araya gelerek temalarını canlandırma, resmetme şeklinde sürdürülebilir.
Çocukların çevrelerine olan farkındalıklarını kuvvetlendirmek amaciyla yukarıda aktarılan oyun bir başka formuyla daha oynanabilir. Öğretmen yeni bir faaliyete geçmek için özel bir kuralı yerine getirmeleri gerektiğini belirtir. "Çocuklar az sonra resim yapacağız ancak bu çalışma için önce sınıfımızdaki sihirli eşyayı bulmamız gerekiyor. Çünkü bu sihirli şey boyaların bütün renklerini içinde saklamış ancak onu bulursak resim yapmamı mümkün olabilecek.." der ve çocukların sınıf içindeki her şeyle ilgilenmelerini sağlar. Çocuklar bir araştırma ve gözlem süreci içinde sınıflarındaki tüm olasılıkları değerlendirirler ve "bu mu? bu mu?" sorularıyla sihirli nesneyi bulmaya çalışırlar. Bir süre sonra öğretmen çocuklardan birinin yanıtını kabul eder böylece çocuklar resim yapmak üzere hazır hale gelirler. $\mathrm{Bu}$ çalışma çocukların her gün içinde bulundukları ortamı faklı bir gözle ve farklı bir amaca yönelik olarak inceleme firsatı sunmaktadır. Sınıf içindeki birçok gözden kaçan ayrıntıya odaklanmak çocuk açısından önemli bir farkındalıktır. Ayrıca her gün rutin olarak yaptıkları bir faaliyet öncesi o faaliyete karşı farklı bir motivasyon sağlaması açısından da önemlidir. Bu çalışma bize yakın ama uzak olan çevremizi keşfetme firsatı sunar. Dramanın kendini ve çevreyi keşfetme süreci bu çalışmada desteklenmektedir.

Düşünme becerilerinin geliştirilmesindeki firsatlardan bir diğeri de problem çözmedir. Drama çocuğun problemlere kendine özgü yollarla çözüm bulduğu, kendini ifade etme yollarından biri olarak, düşünme becerilerinin gelişmesinde etkili rol oynamaktadır. Çocukların buluşçu olarak yetişmesinin öneminin farkında olmayan çok sayıda anne, baba ve öğretmen vardır. Özellikle çocukları küçük yaşta olan aileler için buluş yapma fikri "özel beceri ve yetenekleri gerektiren" sıra dışı bir özellik olarak düşünülür ve bunu başarmanın ancak ileri yaşlarda gerçekleşebileceğine inanılır. Oysaki beyin ve 
çocuk gelişimi ile ilgili çalışmalar göstermiştir ki erken çocukluk yılları çocuğun zihinsel, sosyal, duygusal ve fiziksel gelişiminin temelleri açısından kritik öneme sahip yıllardır. Çocuklar yaşamlarının ilk yıllarındaki eğitsel fırsatlar sayesinde bütün yaşamlarının kalitesini etkileyecek gelişimsel özellikler gösterirler. Özellikle yaşamın ilk üç yılında beyin biyolojik ve fizyolojik olarak en hızlı değişim ve gelişim içindedir. Düşünme becerilerinin geliştirilmesinde hayaller, semboller, çağrışımlar çocukların bağlantılar kurmasını sağladıkları için çok önemlidir. Bugün artık net olarak bilinmektedir ki beynin farklı kaynaklar tarafindan uyarılması beynin gelişimini etkilemektedir. Beynin sol ve sağ yarılarının etkileşime girmesi beyinde çok sayıda yeni ve farklı bağlantıların kurulmasına olanak tanıyacaktır (Bjorklund, 1995).

Buluş yapmak için çocukların doğal merakları ve hayal güçleri onlara yardımcı olur. Burada "buluş" olarak yeni bir icada yönelik ürünün keşfinden bahsedilmemektedir. Çocuğun kendince ürettiği çözümlerden bahsedilmektedir. Albert Einstein "Benim hiçbir özel yeteneğim yoktur ben sadece ölesiye meraklı biriyim." ifadesiyle merakın sonuçlarına dikkatleri çekmiştir. Merak kişiyi araştırmaya yöneltir. Özellikle erken çocukluk yıllarında çocukların gerek kendileriyle gerek ise yakın çevreleri ve dünya ile ilgili merakları çoktur. Meraklarını sorularıyla dile getirirler. Çocuklar yaşları büyüdükçe daha çok soru sormak yerine kendilerine sorulan sinamaya yönelik sorularla karşılaşırlar.

Guilford (1984) genel olarak bireylerin iki tip düşünme boyutuna sahip olduğunu belirtmektedir. Bunlardan biri "yakınsak düşünce" (convergent) olarak tanımlanan çok bilinen yanıtlara dayalı, tek doğru yanıt odaklı, mantıksal, doğrusal düşünme boyutudur. Diğeri ise yaratıcı düşüncenin temelini oluşturan birçok olasılığın varlığına dayanan, orijinal, sıra dış1 fikirler üretmek demek olan "iraksak düşünme" (divergent) boyutudur.
Geleneksel okul çocukların yakınsak düşünceden ıraksak düşünceye geçmesinde kısıtlı olanaklar sunar. Çocukların üst düzey düşünce becerilerinin gelişmesinde rraksak düşünce üretmeleri gerekir. Farklılıklar, çeşitlilikler, olasılıklar, bakış açıları, seçenekler, mecaz, bağlantılar, hayal ıraksak düşünceyi besleyecek olanaklardır. Drama ıraksak düşünme için sosyal firsatlar sunar.

Guilford (1984) yaratıcı düşünmeyi tanımlayan dört zihinsel (esneklik, akıcılık, orijinallik ve yeniden yapılandırmak), dört de duyuşsal alan özelliğinden (merak, karmaşıklık, risk alma ve hayal kurma gücü) bahsetmektedirler. Geleneksel okullar, öğrencilerinin yakınsak yani beklenen olası yanıtlarını pekiştirir, oysaki 21.yy'ın gereksinimlerini karşılayacak olan yenilikçi, girişimci, bilim ve bilgi okuryazarı bireylerdir. Geleneksel okul savunduğu değerler ve öğretim yöntemleriyle 21. yüzyılın gereksinimlerini karşılayamaz. Ancak, raksak düşünmeyi öğrenmeyi destekleyen okul ve ev ortamları yeni yüzyılın yaratıcı, problem çözücü, özgüvenli, benlik algısı yüksek, olumlu bakış açısına sahip bireylerinin yetişmesine destek verebilir.

$\mathrm{Bu}$ nedenle çocukların "ne, neden, nerede, ne zaman, nasil ve kim" sorularıla $(5 n+1 k)$ akıl yürütmelerini sağlamak gerekmektedir. Örneğin okulöncesi çocuklarının çok zevk aldığ 1 aktivitelerden birisi öykü anlatma zamanlarıdır. Hacettepe Üniversitesi Beytepe Anaokulunda "Öykü Bavulu" adı verilen bir aktivite uygulanmaktadır. Bu çalışma sırasında her gün bir çocuk öykü bavulunu evine götürmekte ve ertesi gün okula gelirken istediği özel eşyalarını ya da seçtiği birkaç nesneyi, eşyayı bavuluna koyarak anaokuluna getirmektedir. $\mathrm{Bu}$ aktivite, çantayı dolduran ve okula getiren için gurur kaynağ 1 olurken, diğer çocuklar için de bavuldakilerin tahmin edilmesi yönünde heyecan ve merak kaynağı olmaktadır. Bavulun sahibi bavulda getirdiklerini bazen doğrudan arkadaşlarına göstermekte bazen de ipuçları vererek 
getirdiklerinin neler olduğunun tahmin edilmesini istemektedir. Çocuklar bavuldaki eşyaları kullanarak $\quad 5 \mathrm{n}+1 \mathrm{k} \quad$ soruları sormaya cesaretlendirilirler ve bavulun içindekileri kullanarak öyküler yaratırlar ve birbirlerine anlatırlar. Böylece her çocuğun bavuldaki şeylerle ilgili farklı öyküsü ortaya çıkmaktadır. Son olarak da bavulun sahibi kendi öyküsünü anlatmaktadır. Örneğin bavuldaki bir ayıcık bir çocuğun öyküsünde yolunu kaybetmiş bir ayı iken başka bir çocuğun öyküsünde deniz kenarında kumlarla oynayan bir ayıcık olarak tanımlanabilir. Böylece çocuklar bavuldaki eşyalara verdikleri farklı anlamlarla farklı düşünmenin olasılıklarını somut olarak görmüş olurlar.

Çocukların kendine özgü bir dili bulunmaktadır. Dil ve düşünce eş zamanlı gelişim gösterir. Çocuklar bu anlamda kendi dillerinde konuşurlar. Çocukların kullandığı dil dünyayı nasıl algıladıklarını ve yorumladıklarını gösterir (Bybee \& Sund 1990; Weikart \& Hohmann, 2000).

Dilin anlamsal özellikleri çocuklara anlatılan öykülerle, onların kendilerinin anlattığı öykülerle gelişir. Çocuklar nesnelere ya da fotoğraflara öyküler yaratarak hayal dünyalarını da geliştirirler. Küçük çocuklarla yapılan drama çalışmalarındaki öykü oluşturma, öyküyü canlandırma, cansız nesneleri canlandırma çocukların hem düşsel hem de düşünsel becerilerini geliştirir.

Öğrenilenlerin çoğu iletişimle ilgili mesajlardır, bu nedenle ne öğrettiğimizden çok nasıl öğrenme ortamı yarattığımız da önemlidir. Sevgi ve ilgi, çocukların öğrenme becerilerini geliştirir ve öğrenme kapasitelerini artırır. Tabi ki çocuğun öğrenme ile ilgili entelektüel öz geçmişi ve zihinsel özellikleri de önemlidir ancak bilinmelidir ki öğrenme çocuğun kendisini duygusal ve fiziksel olarak emniyette hissettiğinde tam olarak gerçekleşebilir. Drama bireyin kendisini geliştirme yönünde bir fırsattır.
Özellikle küçük çocukların kendilerini çeşitli şekillerde ifade etmeleri için kaygıdan, rekabetten, mükemmeliyetçilikten soyutlanmış emniyetli bir ortam sağlar (Weikart \& Hohmann, 2000). Düşünsel verimlilik ve yaratıcılık baskı altında engellenir. Çocukların kendilerini rahat ifade edebildikleri ortamlarda akademik performansları da artmaktadır. Düşünme bir üretim sürecidir. Drama bu üretim sürecinin kalitesini dolayısıyla verimliliğini etkilemektedir.

Özetlenecek olursa çocukların düşünme becerilerinin geliştirilmesi onların daha kolay ve daha etkili öğreniciler olmasını sağlayacaktır. Aşağıda çocukların nasıl daha kolay öğrenebileceğine ilişkin temel ilkeler sunulmuştur:

\section{Aktif Katılım}

Öğrenme, öğrenen kişinin aktif, yapıcı katılımını gerektirir.

\section{Sosyal Katılım}

Öğrenme başlı başına bir sosyal faaliyettir ve öğrenmenin gerçekleşebilmesi için okulun sosyal hayatın katılım merkezi olması gerekir.

\section{Anlamlı Faaliyetler}

İnsanlar en iyi şekilde gerçek hayatlarına faydalı olacak ve gereksinimleriyle ilgili faaliyetlere katıldıkları zaman öğrenirler.

\section{Yeni bilgiyi önceki bilgiler ile}

\section{ilişkilendirmek}

Yeni bilgi hali hazırda anlaşılmış öğrenilmiş olanların temelleri üzerine inşa edilir.

\section{Stratejik olmak}

İnsanlar anlamalarına, hatırlamalarına ve sorunları çözmelerine yardımcı olacak etkin ve esnek stratejiler ile öğrenirler.

6. Özdenetim ve öz yapılandırma, önceki bilgileri yeniden yapılandırmak

Öğrenen kişiler öğrenmelerini nasıl planlayacaklarını ve izleyeceklerini, kendi öğrenme hedeflerini nasıl belirleyeceklerini ve hataları nasıl düzelteceklerini bilmelidirler. 


\section{Ezberden çok anlamanın hedeflenmesi}

Öğrenme ezber ve izole durumların temel alınmasından çok genel prensipler ve açıklamalar doğrultusunda organize edildiği zaman daha iyi gerçekleşir.

\section{8.Öğrencilerin transfer etmeyi ögrrenmelerine yardımcı olmak}

Öğrenme süreci ve ürünleri gerçek hayatta uygulandığı zaman daha anlamlı bir hal alır.

\section{Alıştırmaya vakit ayırmak}

Öğrenme bilişsel bir faaliyettir, süreç içinde gerçekleşir, aceleye getirilemez. Bir alanda uzmanlık oluşturmak için önemli bir zaman ve uygulama dönemleri gerektirir.

\section{Gelişimsel ve bireysel farklılıklar}

Çocuklar en iyi bireysel farklılıkları göz önüne alındığında öğrenirler.

\section{Güdülenmiş öğrenciler yaratmak}

Öğrenme öğrenenin motivasyonundan etkilenir. Öğretmenler öğrencilere hal ve tavırları ve ifadeleri ile daha motive olmuş öğrenenler olmaları için yardımcı olabilirler (Vosniadou, 2004).

Yukarıda sayılan öğrenme kolaylaştırıcılarının tamamının kullanıldığı deneyim alanı dramadır. $\mathrm{Bu}$ nedenle dramanın çocuk gelişimi için sunduğu bu şansı iyi kullanmak gereklidir.

\section{Kaynaklar}

Aster, V. E. (1994). Bilgi Teorisi ve Mantık. Çev: Macit Gökberk. İstanbul: Sosyal Yayınları.

Alexander, R. J. (1995) Versions of Primary Education. London: Routledge.

Baklaya, İ. \& Tuğrul, B. (1998). Anaokuluna yeni başlayan çocukların okula uyum süreçlerini etkileyen faktörlerin incelenmesi. Hacettepe Üniversitesi Ev Ekonomisi, 2, Ankara.

Bjorklund, F.D. (1995). Children's Thinking. Developmental Functions And Individual Differences. London: ITP.

Bybee,W.R., \& Sund,B.R. (1990). Piaget for Educators. USA: Waveland Press.
De Bono, E. (1992). Teach Your Child How To Think? Newyork: Viking Publication.

Dodge,D.T., Colker,J.L., \&Heroman, C. (2002). Creative Curriculum For Preschool. USA: WDC.

Gardner, H. (1995). Reflections on multiple intelligences. Myths and messages. Phi Delta Kappan, 77, 3, 200 - 209.

Gelb, J.M. ( 2004). Leonardo Gibi Düşünmek. Çev: Tuncer Büyükonat. İstanbul: Beyaz Yayınları.

Guilford, J.P. (1984). Varieties of divergent production. Journal of Creative Behavior, 18, 1 -10.

Isenberg, P.J.,\&Jalongo, R.M. (2001). Creative Expression And Play In Early Childhood. New Jersey: Merrill Prentice Hall.

Prashnig,B. (1996). Diversity Is Our Strength. The Learning Revolution in Action. New Zealand: Profile Books.

Sungur, N. (1997).Yaratıcı Düşünce. Ankara: Evrim Yayınevi.

Tuğrul,B. (2005). Çocukta Yaratıcılık ve Drama. Eskişehir: Anadolu Üniversitesi Açıköğretim Fakültesi Yayınları.

Tuğrul, B. (2007). Hacettepe Üniversitesi Beytepe Anaokulu Eğitim Programı Uygulamaları, Ankara.

Oktay, A. (2000). Yaşamın Sihirli Yılları, İstanbul: Epsilon Yayınc1lı.

Tipton, D. (2001,September). How your children think and learn. Teaching/Learning Styles And Methods: Pedagogy , from Lesson Tutor.

Weikart ,P.D. \& Hohmann, M. (2000). Küçük Çocukların Eğitimi. İstanbul: Hisar Vakfı Yayınları.

Wood, D. (1999). How Children Think And Learn. USA: Blackwell Publications.

Uniceff (2006). Dünya Çocuklarının Durumu: Dışlanan Ve Görülmeyen. Uniceff Türkiye Temsilciliği, Ankara.

Vosniadou, S. (2004). How Children Learn. UK, Educational Practices Series-7. 


\title{
Summary \\ Drama as a Creative Process for Developing Thinking Skills in Preschool
}

\author{
Belma TUĞRUL
}

\author{
Hacettepe Üniversitesi
}

Earlychildhood period named also as earlychildhood years is the period of growing, learning, playing, and feeling confident for the children. Earlychildhood period includes the six years before the elementary school. This period can be called as crucial with respect to its physical, social, emotional, and cognitive dynamics. The development of thinking skills of children is a dynamic period. Knowing how do thoughts of children change is essential to make a proper and effective communication between children. The thoughts of children are valuable since they are the product of their emotional and cognitive periods. The behaviors are the concrete ways of thoughts. Because of this fact, it is necessary to know the thoughts of the children's behaviors to make an objective interpretation about their behaviors.

Children deserve the special attention and support since they are the adults of the tomorrow. This attention and support should be given since their early years. It is an obvious fact that, children can sometimes be blocked in expressing their ideas and emotions in adults world even if it is not on purpose. Particularly the children in early ages might have some trouble in competencies. However children are the heroes of their ages. Giving respect to them is a child right in the world. To respect this child right, it seems to be essential to remind particular information about how children think.
According to Piaget the period of learning for children means accommadation to the world. Adaptation of child's previous knowledge to new ones is a cognitive process which reflectsdirectly child's thinking skills. Piaget explains the cognitive actions of a child as a result of his or her thinking. It is expected that children can not think as adults do (Bjorklund, 1995). There are many sources for children to learn, and it is up to children to utilize those sources in favor of his or herself. Thinking is the most common activity for children. In addition to this, adults understand about children's thinking less frequently. Bono (1992) emphasized that adults should enhance their thinking abilities by the help of children' view of world.

Thinking is an enjoyable process for children because they play their thoughts. In addition to feeling freedom while thinking, the excitement of investigating something makes thinking enjoyable (Wood, 1999; Vosniadou, 2004). However in traditional schools, the children take risks because of their thinking since there is a high expectation from the children about involving in a common concius. As Rousseau (cited in Alexander, 1995) implied "...childhood has special way of seeing, thinking and feeling; it would be very inaccurate to force children to think in our ways". It is important to make children notice their differences, but the most important thing is to encourage children to be different. One of the basic needs of human beings is acceptance from 
others (Isenberg \& Jalongo, 2001). However, for children waiting for acceptance for every behavior from adults is an obstacle for improvement.

Most of the teachers are afraid of children's uncommon thoughts since it is difficult to handle uncommon ideas for incompetent teachers. One of the important thing is to believe the necessity for creative thinking which can be improved by the help of creative teachers and parents (Isenberg \& Jalongo, 2001). Children need creative models to be aware of their power for creativity. For being such a model, the easiest and practival way is to ask questions. Improving thinking can be made by asking questions. The purpose of education is not to give knowledge, emotion and thought to the children, in contrast, it is aimed to develop creating positive attitudes, thoughts and emotions, arousing the curiosity in children. The conventional way of schooling focuses on not asking questions, on finding the only correct answer. Finding the right answer is valuable in these schools. On the other hand, the natural curiosity of children gives emphasis on the questions. It is important to ask the right question not to get the right answer and encourage students to ask the questions that are never asked (Prashing,1996). Drama is one of the effective methods in developing children's thinking skills. The drama activities especially with the children in early ages have an impact on evoking the experiences which are real, concrete and only belong to the children (Tuğrul, 2005). 